\title{
Ghoshal's Ghost: Financialization and the End of Management Theory
}

\author{
Gregory A. Daneke ${ }^{1} \cdot$ Alexander Sager $^{2}$
}

(C) Springer International Publishing AG 2015

\begin{abstract}
Sumantra Ghoshal's condemnation of "bad management theories" that were "destroying good management practices" has not lost any of its salience, after a decade. Management theories anchored in agency theory (and neo-classical economics generally) continue to abet the financialization of society and undermine the functioning of business. An alternative approach (drawn from a more classic institutional, new ecological, and refocused ethical approaches) is reviewed.
\end{abstract}

Keywords Agency theory - Complexity theory · Financialization - Institutional economics · John Rawls · Thorstein Veblen

London Business School Professor, Sumantra Ghoshal (2005) caused a furor, albeit fleeting, with his assertion that "bad management theories" were "destroying good management practices". Ghoshal took academics to task for promulgating false and morally suspect ideas and insisted that they were partly to blame for managerial actions in a number of corporate scandals (e.g., Enron and Tyco). Ghoshal echoed the earlier concerns of business ethicists (e.g., Bowie and Freeman 1992) that scholarship and teaching (especially in leading US business schools) was anointing an increasingly self-destructive worldview derived from neo-classical and neo-institutional (e.g., Williamson 1985) economic theory and applied to critical issues of corporate strategy and governance. The on-going financial crisis, which came to public attention in 2008, has more than vindicated his contentions; and yet, both the financialization of society and the pedagogy proceed apace.

We revisit and re-develop Ghoshal's criticisms and show that business schools have yet to fully acknowledge how their role in the crisis demands the rehabilitation of management

Alexander Sager asager@pdx.edu

Gregory A. Daneke daneke@asu.edu

1 W.P. Carey School of Business, Arizona State University, Tempe, AZ, USA

2 Portland State University, Portland, OR, USA 
theory. Though there has been some progress in adding business ethics, corporate social responsibility, and sustainability curriculum, there has been less assessment of the nature or purposes of management theory itself. Management theory, in its quest for rigor and scientific legitimacy, has continued to draw heavily on economic ideas that are either in themselves questionable or have limited application for management. The formulation of a more adequate management theory demands a critical analysis of the role of business in society and a reexamination of how the social sciences best inform management practices.

What is needed is a positive research program that allows theorists to move toward a new management paradigm. Ghoshal and others have mounted impressive criticisms of management theories informed by the neo-classical synthesis, but have not offered a systematic, alternative framework that draws on other developments in social sciences. Management theorists, if they are to compete with the dominant paradigm exemplified by the Chicago School, need another set of concepts and tools to move forward. In particular, they need to combine a theory of human agency, a conception of the firm, and a diagnosis of the larger social and economic world. Our goals are to build upon and reinforce criticisms put forward by other scholars against what Ghoshal dubbed "bad management theories" (2005) and also to begin to define an intellectual space for better theories to emerge.

\section{Bad Management Theory in the Age of Finance Über Alles}

Ghoshal's central claim is that management as a profession has been damaged by the prevailing economic paradigm that combines neo-classical models with the values and practices of the current age of financial capitalism. Management theorists exported mistaken assumptions about rationality from neoclassical micro-economics that do not accurately represent human nature, allow for the construction of plausible moral agents, or support a cogent moral theory.

As Ghoshal points out, neo-classical notions not only came to dominate economics courses, they pervaded management curriculum generally. He associates this contagion with the rise of Agency Theory (see: Eisenhardt 1989) which maintains that primary role of management is to adjust the interests of the managers (agents) with those of the shareholders (principals). Ghoshal chronicles how this theory as well as the tools of neo-classical organizational economics (e.g., transaction costs) came to pervade courses in corporate governance, organizational design and corporate strategy. Building upon Ghoshal, Matthias Huehn (2008) maintains that a virulent strain of "unenlightened economism" was transmitted into the society at large via the "Trojan Horse" of management theory. This allowed a misguided "ideology" to displace a "scientific research programme". This is the real impact of Ghoshal's indictment that we refer to as his ghost; in essence, leading business schools have fortified this socially destructive ideological movement by disseminating dubious theories. This movement, which corresponds to the widespread financialization of society (see: Dore 2008; Christopherson et al. 2013), undermines the basic empirical as well as ethical functions of business enterprise and may even portend the end of management theory per se.

Finance, of course, is a vital element of all business enterprises, but the concept of financialization connotes a distortion of these basic activities so that the finance tail not only wags, but also eats the management dog. The financialization of the firm, which corresponded to the assertion of the shareholder primacy, was merely the tip of the iceberg. The financial services industry, broadly defined as FIRE (Finance, Insurance and Real Estate), became in the words of Kevin Phillips (2006), "the dominant economic, cultural, and political role in the 
national economy (p. 268)." While financial institutions (e.g., underwriting and trade companies, corporate trusts and investment banks) have reigned over the bulk of economic activity in the past (especially prior to the US Civil War, the "Gilded Age" prior to WWI and prior to the Great Depression and WWII), the current financial epoch is unprecedented in scale and scope, and its current influence upon managerial activity is immense. The most troubling aspect of this re-established deus ex machina is the unparallelled level of political protection (ergo the "too big to fail" banks) and how this edifice was carefully constructed and cloaked in "free market" rhetoric (see: Mirowski 2013; also note: Stedman-Jones 2012). What is now called "financialization" comprises a number of societal processes. As Gerald Epstein (2005) summarizes, "financialization means the increasing role of financial motives, financial markets, financial actors, and financial institutions in the operation of the domestic and international economies (p.3)." Greta Krippner (2005) further defines it as a "pattern of accumulation in which profit making occurs increasingly through financial channels rather than through trade and commodity production (p.174)." A hallmark of financialization, according to Ronald Dore (2008), is "the increasingly strident assertion of the property rights of owners as transcending all other forms of social accountability for business corporations" (p. 1098). This assertion of property rights has primarily taken the form of shareholder value maximization - in fact, some see shareholder primacy as the foundational ideology for our present hyper-financialized epoch (van der Zwan 2014).

\section{Myopic Meaning of Management}

The dominant management philosophy became the handmaiden of the new and increasingly destructive version of global finance, despite alternative approaches in the scholarly literature. Some scholars have reintroduced neo-Keynesian approaches after the global financial crisis (Whalen 2013). Critical Management Studies (Grey and Willmott 2005) has received a fair amount of attention with its incorporation of post-structuralist (Jones 2009), Marxian (Adler 2007), and feminist insights (Martin 2003). Ecological and evolutionary approaches (Daneke 1999; Haidt and Wilson 2013) such as the one we advocate here also have some traction among theorists. Nonetheless, these alternatives have not been able to displace even a small portion of the dominant neo-classical economics paradigm in the majority of business schools. Despite their complicity in the on-going global financial crisis (Krugman 2009), most business school economists remain firmly unrepentant. One of most powerful and pernicious manifestations of neo-classical model of the firm is the exaltation of shareholder interests. As Susan Murray (2013) reported, once the shareholder primacy model was firmly implanted into leading US business schools it would not be easily extricated, especially from within the burgeoning finance, accounting, and business law departments. Despite much controversy (see: Freeman and Bowie 1992), the myopic viewpoint that the sole responsibility of management was to increase shareholder value has become thoroughly embedded in business scholarship, especially in the U.S.

From the blending of neo-classical economics, contract law, and organizational inquiry, this trend was substantially buttressed by the advent of agency theory. Agency theory sought to resolve conflicts between principals and agents, especially under circumstances of uncertainty and of asymmetrical information, where the principals (managers) are expected to shortchange the agents (shareholders) of their rightful share of the profits. The principal-agent problem is 
based on the assumption that there is always a potential conflict between the desired outcomes of the principal and the agent (Jensen and Meckling 1976: 308). Jensen and Meckling endorse a conception of human nature that sees people as "resourceful, evaluative maximizers" who "respond creatively to the opportunities the environment presents them ... and work to loosen constraints that prevent them from doing what they wish to do." (Jensen and Meckling 1994: 19). When applied to the relationship between managers and shareholders, Jensen's model of human nature maintains that managers (agents) must be incentivized to act in the interests of shareholders (principals) and that firms must be structured to mitigate self-interested behavior. Particular recommendations include using stock options to compensate executives, dediversifying industries, the use of debt rather than profit to finance new projects, and encouraging more independent boards to exercise increased oversight of managers.

The philosophy of shareholder primacy rose to canon law despite its reliance on a mistaken interpretation of corporate law - shareholders neither "own" the firm, they are not the sole residual claimants, nor are managers legally agents of shareholders (Stout 2012: 22-46, c.f. Smith and Ronnegard 2014) - and despite mixed results from the perspective of shareholder interest (Dobbin and Jung 2010). Meanwhile, the notion that managers had broader responsibility to stakeholders (employees, customers, suppliers, and the community at large) declined with the Business Roundtable policy statement moving from a broad acknowledgement of responsibility to stakeholders in 1990 to an almost exclusive focus on shareholders by 1997 (Khurana 2007: 320-1)

Much of the intellectual infrastructure of shareholder primacy was provided by Oliver Williamson (1975 and 1985). It was Williamson (1964) who originally identified "managerial discretion" as a hypothetical problem back in the 1960s. Seeking to defend neo-classical economics against the "behavioral theory of the firm" (Cyert and March 1963), he refashioned institutional analysis to exclude the cultural factors so vital to traditional institutional economics (e.g., Veblen, Common, etc.). Williamson built an elaborate organizational edifice with Pareto efficiency as the only legitimizing process. Williamson went well beyond basic selfinterest with the stronger notion of opportunism in which individuals are constantly engaged in strategic behavior in pursuit of personal advantage. Opportunistic human nature lends itself to a conception of the organization that relies on hierarchical control: "absent opportunism, there is no contractual reason to supplant market by hierarchy." (Williamson 1998: 31) The result enshrined shareholder primacy as the dominant managerial paradigm.

Just as Williamson shifted the unit of analysis from the rational individual to the boundedly rational transaction, economists who studied industrial organization needed new concepts of competition. Game theorists had already saved neo-classical theory from its flawed notions of equilibrium by substituting strategic processes (Nash Equilibrium) for Walrus's mythical auctioneer. Michael Porter $(1980,1985)$ extends the logic of games to the level of entire industries and shows how firms co-exist rather than compete. According to Porter, firms seek to find their ecological niche via a field of "five forces": 1) industry competitors, 2) new rivals, 3) substitute products and services, 4) the bargaining power of suppliers, and 5) the bargaining power of buyers. A successful "strategy can be viewed as building defenses against the competitive forces or as finding positions in the industry where the forces are weakest." (Porter 1980: 30) Essentially strategy boils down to avoiding competition.

While brilliant at the game-theoretic and textbook level, in application "sustainable advantage" is illusive. The most successful element appears to be manipulating government regulators into erecting barriers to new entrants (see: Stewart 2009). In a hyper-financialized economy, it is not even clear that the shareholders were all that well served by Porter. As his 
Harvard colleague Clayton Christensen (1997) suggests, those firms that thought they had found their defensible niche, and financed themselves out of R\&D, were displaced by technological advances. At root the five forces assume a static, zero-sum account of the economy, rather than a dynamic, positive sum game made possible by innovations (Ghoshal and Barlett 1997: 276). Porter asks companies to appropriate value from their employees, their customers, their suppliers, and rival companies. The problem with this view of strategy, according to Ghoshal, Bartlett, and Moran (1999) is that "the interests of the company are incompatible with those of society." (p.12) They add that, under Porter's five forces, "The destruction of social welfare is not just a coincidental by-product of strategy; it is the fundamental objective of profit-seeking firms and, therefore, of their managers" (p.12). Porter's approach to competition reduces business to value extraction rather than value creation (Ghoshal, Bartlett, and Moran 1999).

These three theories combine to the detriment of managers who follow their prescriptions. In Ghoshal's words:

Combine agency theory with transaction costs economics, add in standard versions of game theory and negotiation analysis, and the picture of the manager that emerges is one that is now very familiar in practice: the ruthlessly hard-driving, strictly top-down, command-and-control focused, shareholder, value-obsessed, win-at-any-cost business leader of which Scott Paper's “Chainsaw” Al Dunlap and Tyco's Dennis Kozlowski are only the most extreme examples (Ghoshal 2005: 85).

\section{Management in CRISIS: Plus ça Change, Plus c'est la Même Chose}

Ghoshal saw a direct link between ideology and business scholarship and scandals at the turn of the new millennium (e.g., Enron, WorldCom, and Tyco), but leading business schools have not yet fully acknowledged these links. The burst of the dot com bubble provoked a flurry of articles and conferences among management theorists calling for more attention to ethics in business schools (Adler 2002; Melé 2008). The Association to Advance Collegiate Schools of Business convened a task force that issued a report with a series of recommendations that business schools increasingly integrate ethics into their curricula (AACSB International 2004). Surveys of students routinely suggest a growing concern for ethical issues. Christensen and her colleagues (2007), found that in $200672 \%$ of the top 50 business schools in the Financial Times Ratings had a Net Impact Chapter - a proxy for student interest in CSR and sustainability - and that a third of the 50 top global MBA programs included ethics, corporate social responsibility, and sustainability in the curriculum. They also noted a number of new centers and institutes dedicated to ethical topics. The Aspen Institute Beyond Grey Pinstripes survey reported a marked increase in required courses in social, ethical, and environmental issues, including an increase from $34 \%$ in 2001 to $79 \%$ in 2011 of schools that have a required course on business and society issues ${ }^{1}$ and a decline from $75 \%$ in 2001 to $64 \%$ in 2007 of MBA students who view the primary responsibilities of a company to include the maximization of shareholder value (West 2011). Though these developments are encouraging, they are peripheral to Ghoshal's criticisms. Management theory itself has not fundamentally changed since the turn of the millennium (Hühn 2014).

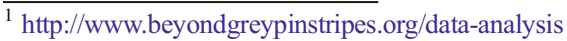


The problem is that management theorists have tended to see the normative issues of business to be a matter of applied ethics concerning the obligations of individual managers or companies. This results in the conceptualization of business - e.g., its responsibilities toward shareholders and stakeholders - in isolation from broader institutions (Heath et al. 2010). Ethics is too often identified with a set of abstract theories - utilitarianism, deontology, social contract theory, virtue ethics, etc.-or with indeterminate deliberation on hard cases (Donaldson 2008: 303-4). More "practical" approaches frequently reduce ethics to administrative or legal rules - e.g., codes of conduct or guidelines for avoiding conflicts of interest. These approaches to business ethics education distract management professors from rethinking the role of business, the nature of management, and the larger socio-economic-legal system. Moreover, the effects of education on people's behavior are complex. Isolated courses in ethics, sustainability, or corporate social responsibility are unlikely to have a major impact on future managers' actions (Waples et al. 2009).

Instead, the normative issues confronting managers need to be situated in complex social, legal, and political systems with attention to the feedback mechanisms between public policy and private enterprise. Given the dominance of agency theory's model of human nature, its view of markets, and its normative vision of society in many business circles, it is necessary to refute or at least cast into doubt many of the ideas drawn from neoclassical economics, to show how these ideas reduce social wellbeing, and to offer an empirically plausible and normatively viable sketch of an alternative theoretical framework.

\section{A More Social Science}

Management theories are both social sciences and societal technologies. The grandfather of behavioral and complexity economics, Herbert Simon (1996), maintains that most social sciences, and particularly those involved in the administration of human affairs, are actually "design sciences" (more like architecture and engineering). As a design science for the social world, management is a normative project. Management is a social technology and all technologies have a telos (a purpose). Management has explicit normative aims embedded in its nature and exists to fulfill certain social functions. As such, it is an ethical enterprise (Solomon 1993, 2004).

The artificial separation of business and ethics and of economics and politics is only possible because of a misconception of the basic nature of management due in part to its reliance on the value-free mythology of neo-classical economics. Business schools chose to emphasize neo-classical economics without careful attention to its actual scientific integrity or its ideological baggage (see: Mirowski 1991, 2004; Schlefer 2012). The economics taught in business schools remains to this day largely ahistorical and path independent, and with little concern for socio-cultural evolution. The conceptual limitations of neo-classical economics, particularly when it is applied to the theory of the firm, emerge from a normative view of human nature, business, and the good society. More damningly, the ideas of neo-classical economics presented as truths about human nature and necessary restrictions on markets and firms, entail a deterministic world view in which current arrangements are more or less inevitable (Ghoshal 2005: 79).

In neo-classical theory, rationality is defined as the instrumental reasoning of self-interested individuals satisfying their preferences. Though agency theory allows for partially bounded rationality and herd responses explained using behavioral economics (e.g., Simon 1959), homo 
economicus remains pretty much intact and serves as a foundation for business education. For the most part this narrow caricature of economic man (person), as rational, self-interested, hedonist (maximizing their individual utility at the margin) is translated into institutionalized expectations. As employed by Williamson, Jensen, etc., agency theory is not neutral with regard to behavior. Rather, it assumes the worst.

A new social scientific foundation is needed, one anchored to our basic understandings of human behavior and socio-cultural evolution. As Ghoshal explains, "common sense has, of course, always recognized that human behavior can be influenced by other motives. Increasingly, empirical evidence provides overwhelming support to what common sense suggests" (Ghoshal 2005: 83). Some of the more interesting empirical work extends the insights from the study of common pool resources (Ostrom 1990) with earlier institutional inquiries (e.g., Veblen and Commons) toward an understanding of the cooperative basis of human enterprise. This research draws upon anthropology, psychology, behavioral economics, and game theory as well as recent advances in computational sciences (Fehr and Fischbacher 2003; Gintis, et al. 2005; Henrich et al. 2005; and Henrich 2006). These studies combine ethnographic field work with experiments, as well as simulations of artificial adaptive agents (the latter providing "an artificial reality check for economists"). They explore the flourishing of what they call "homoreciprocans" (boundedly rational, other-regarding, and relentlessly seeking fairness) and they illustrate how these socially oriented behaviors participate in institutional change and sociocultural evolution (Gintis et al. 2005; Bowles and Gintis 2011). Among other things, this research allows for the possibility of altruistic behaviors having significant cultural presence. Heretofore those economists who admitted that altruism even existed merely assumed that it would be destroyed in the aggregate by all the greedy agents. In contrast, it is often the selfishness that is crowded out by other-regarding behavior (Fehr and Fischbacher 2003).

Throughout human history, other-regarding motivations are paramount (see: Boehm 2012), and despite economists' attempts to convince us otherwise, these and similar values (e.g., justice) shape behavior (see: Gintis 2006). People care about others' well-being and view their own well-being as bound up in the fate of others. In fact, an examination of the anthropological record demonstrates how remarkably little opportunistic behavior actually occurs (Boehm 2012). Social sanctions against opportunistic behavior functioned precisely because most members of the group had internalized cooperation and altruism as the norm. As Elizabeth Anderson shows, neither rational choice theory nor evolutionary theory has been able to fully explain people's commitment to social norms. Instead, an explanation of practical reasoning needs an account of homo sociologicus (Anderson 2000: 171) in which action derives from people's self-understanding - what counts as a reason depends on the fact that people "understand one another to be jointly committed to some goal, belief, or principle of action." (p.192).

\section{Management Breaking Bad}

This is not merely an academic debate. Agency theorists make a suspect inference from the observation that people can be self-interested or opportunistic to the claim that the primary consideration in designing institutions is the reduction of self-interested or opportunistic behavior. Humans are reflexive animals who not only interpret the world but also interpret themselves. For this reason, social scientific theories can create self-fulfilling prophecies (Ferraro et al. 2005; Giddens 1984). People's degree of opportunism may depend on 
institutional structures and on assumptions people have learned about people's likelihood to behave opportunistically (Ghoshal 2005: 77).

To the extent that management is a social process, it is inexorably interwoven with imposition of societal values. The entanglement of fact and value does not necessarily erect a barrier to scientific understanding and explanation (Putnam 2002). It does, however, demand that scientists think carefully about and justify the values embedded in their theories and practices. Management is a normative enterprise that seeks to intervene in the social and economic worlds and that either explicitly or implicitly contains a theory of ethics. Business is justified by its ability to produce and distribute goods and services more effectively than alternative institutions and management's purpose is to facilitate this.

This brings management into the scope of political philosophy. Business is essentially a set of social arrangements that "distribute fundamental rights and duties and determine the divisions of advantages from social cooperation" (Rawls 1999: 6) and include "the legally recognized forms of property, and the structure of the economy" (Rawls 2001: 10). Business interacts with other legal, political, and social institutions to determine the distribution of resources (Moriarty 2005). It is thus subject to philosophical criticism and justification regarding its role in promoting or undermining distributive justice.

Though Robert Solomon called for an approach to business ethics that integrates studies of the corporation and individual behavior within larger questions of justice twenty five years ago (Solomon 1990), there has been limited dialogue between business ethicists and political philosophers (Heath et al. 2010; see: Donaldson and Dunfree 1994; and McMahon 1994 for notable exceptions). In fact, the only well worked out political philosophy that integrates "micro-level business ethics and midlevel corporate governance in theories of the firm and a macro-level justification of markets and government regulations" (Norman 2012: 35) is the Chicago School. The Chicago School's normative assumptions are cloaked in supposedly value-free claims about the social science of individual agency and the nature of the firm that we have been criticizing. Moreover, many political philosophers reject its conception about the proper relationship between government and markets on conceptual and normative grounds. Unfortunately, these critics have for the most part neglected how macro-level theories of justice should inform and be informed by meso-level theories of the firm and by micro-level theories about individual agency. This has allowed management theorists to incorporate the assumptions of the Chicago school without considering viable alternatives.

Management theorists need to reflect on the principles of distributive justice (Rawls 1999; also note: Alexander 2000) and ask how business contributes to the distribution of benefits and burdens across society. Business and markets serve to create value in conjunction with other institutions (e.g., political rules governing redistribution). The question is how they are able to more efficiently produce and more justly distribute goods and services. Reasonable people disagree about the basis and scope of distributive justice and the institutions that are most likely to meet its requirements. Nonetheless, bringing the insights of political philosophy into management theory will not occur until there are well-developed alternatives to the Chicago School that make their normative commitments explicit.

There are already well-developed theories in political philosophy that offer political theories that combine micro-level accounts of moral agency with macro-level accounts of distributive justice. One way forward would be to work within the liberal egalitarian tradition established by John Rawls to situate management theory within a larger vision of distributive justice as well as an account of individuals as moral agents (Mazie 2011). Another possibility would be to follow Amartya Sen who has also developed his capability approach and his work on agency, 
rationality, and democracy into a theory of justice (Sen 2011). Candidates in the utilitarian, libertarian, feminist, and Marxian traditions also deserve consideration (Lamont and Christi 2014). Philosophers of management need to engage with these theories and see how they can integrate the meso-level of the firm and more generally explore their implications for business.

Whatever the precise contours of a plausible vision of justice, agency theory and the Chicago school miss the mark. The normative debate between agency theory and its critics centers on the distinction between value destruction and creation. The prime directive of management is value creation, broadly defined. As Ghoshal, Bartlett, and Moran (1999) observe, companies exist precisely because markets do not create value. We need firms which allow for purposive adaptation to situations in which market mechanisms are not present. Beyond the need for managers to create value if they are to play a role in a just society, we need to ask about the distributive effect of management practices. Business alone does not determine the distribution of benefits and burdens across society, but its practices - and how these practices are regulated-are momentous.

Ghoshal's case against agency theory can be buttressed by showing how the on-going financial crisis teaches us that much of what passes for management actually destroys value. David Korten (2010) contends that much of business scholarship does not distinguish between "phantom wealth and real wealth", the former being essentially destructive of societal value. Korten explains that phantom wealth

...includes financial assets created by debt pyramids in which financial institutions engage in complex trading and lending schemes using fictitious or overvalued assets as collateral for loans in order to feed and inflate asset bubbles to create more phantom collateral... (p.21)

This diversion of resources from the productive to the unproductive economy is most noticeable in declining rates of investment in technological innovation (Lazonick and Mazzucato 2013). Financialization and the ideology of shareholder primacy, according to William Lazonick and Marianna Mazzucato, undermines innovation and prosperity. Specifically, they maintain that they confuse creating value with extracting value through rent-seeking (Olson 1982, 2000). These criticisms were well-known by the Institutionalists, something William Baumol (2004) emphasizes in drawing upon Henry George's classic, Progress and Poverty (1879) to raise an important distinction between an authentically entrepreneurial society and a society that muddles entrepreneurship and rent-seeking and inordinately rewards "unearned wealth" (also see: Baumol 1990).

The current trajectory of financialization dramatically increases inequality (of both opportunity and result) and insecurity (both personal and national), as well as economic instability (see: Epstein 2005; Dore 2008; and van der Zwan 2014). Beyond the stock pumping incentives, skyrocketing executive remuneration, de-unionization, off-shoring, and the proliferation of financial intermediaries (from private equity and hedge funds to payday loan companies), financialization has heralded the greatest upward transfer of wealth in the history of humankind. Meanwhile unlimited leverage and the explosion of increasingly exotic and decreasingly regulated derivatives markets raised the level of inherent instability (see: Minsky 1992) of global "systemic risk" to astronomical levels (Haldane and May 2011). If stagnating wages and diminishing job security were not enough for members of the declining middle class to contend with, the "financialization of everyday life" (Martin 2002; van der Zwan 2014) makes them personally responsible for all the risks that the quants with their myth-ridden financial theories (see: Perez Caldentey and Vernego 2010) cannot begin to comprehend. 


\section{From Financialization to the Re-Institutionalizing Management Theory}

We have made the negative case that many of the elements of bad management theories stem directly from their overreliance on neo-classical theories that exclude normative, cultural, and political, as well as economic realities (e.g., institutional evolution and non-equilibrium). A sustained engagement with the impacts of financialization spells an end for management theory based on shareholder primacy and raises fundamental issues of identifying stakeholders. The major debate is not between shareholder primacy and more balanced stakeholder approaches, but rather about the purposes of the firm and its place in larger social systems. This is a normative investigation to identify the values that firms are responsible for promoting and an empirical investigation to identify tools from the social sciences that increase our understanding of business and its functions, as well as to help craft management theories that support prosperity.

Business schools should refashion their curriculum upon a foundation of theories which explain the role of business institutions in the evolution of society, as well as restore the ethical content of the management profession. This would focus attention to demands of justice given business's role as the major economic institution in contemporary society. Management theory should be built on insights of theorists who have sought to understand the implications of financialization during its previous incarnations and who base their theories in a conception of social and economic justice grounded in a more compelling theory of human nature.

In order to start to restore these elements we turn to the institutional economics from a bygone era. Despite its vintage, it is much more scientific in its basic orientation, including perspectives from a range of social sciences, as well as evolutionary dynamics. Hence it readily links with emerging notions of homo sociologicus (Anderson 2000), as well as the results emerging from the realm of complexity economics (Kirman 2011; Arthur 2013). Gregory Daneke (1999) referred to this terminus of old institutional economics and new complexity science as "institutional ecology (see: Fig. 1)." It is noteworthy that the old institutionalists experienced firsthand the social turbulence brought about by previous periods of widespread financialization, and thus provide invaluable insights into our on-going crisis.

An important part of our argument throughout has focused on how management theory interacts with and indeed encourages financialization. When we speak of the end of management theory, it is because those pieces of ideology that maintain the shareholder primacy notion in the leading business schools are reduced to absurdity in a world of rabid financialization. They make a virtue out of predation, and in the process they imperil the "prime directive" of management to extend human organizational capabilities to produce greater prosperity. By recasting Ghoshal's observations that business education is rotten at the core, and augmenting his perspective with the recognition that these "bad theories" emerge from predatory economic practices, perhaps we can provide a new starting point.

Much of the work on values, pro-social norms, and evolution, is done under the rubric of "Complexity Theory", and thus provides an alternative approach to macro-structures as well as micro-behaviors. Brian Arthur (2013) explains that the most distinguishing feature of complexity is its focus on non-equilibrium dynamics, while neo-classical economics remains preoccupied with equilibrium. He explains that

Where equilibrium economics emphasizes order, determinacy, deduction, and stasis, complexity economics emphasizes contingency, indeterminacy, sense-making, and openness to change...This view, in other words, gives us a world closer to that of 
Traditional Institutional Concerns (norms, culture, individual traits, and political power shape the course of industrial transformation).

๑ Collective Behavior (bounded rationality, cooperation, altruism, fairness, and reciprocation shape individual choices).

๑ Path Dependency (time, history, and technological lock-ins, as well as adaptive and exaptive combinations produce enduring patterns).

๑ Emergence (interactions produce perpetual novelty and emergent properties so that whole is greater than sum of its parts).

- Nonlinearity (feedback driven distortions, chaotic and cascading effects, as well as farfrom equilibrium dynamics).

( - Co-evolution of Agents and their Institutions (Agency as well as self-organization; involving biology as well as rules, rituals, regulation; and designs).

๑ Complexity Science Tools (bottom-up simulations using adaptive algorithms, cellular automata, evolutionary games, fuzzy sets, and safe-fail resiliency tests).

*Adapted from Daneke, 1999

Fig. 1 Elements of institutional ecology*Adapted from Daneke 1999

political economy than to neoclassical theory, a world that is organic, evolutionary, and historically-contingent (pp. 1-2).

He proceeds to provide numerous examples, including those from on-going financial crises, to demonstrate that economics should be primarily about non-equilibrium. Many of the critical issues relevant to managers are not those of "allocative efficiency thought markets". Rather they involve issues of "formation". Arthur explains that formation involves:

...how an economy emerges in the first place, and grows and changes structurally over time. This is represented by ideas about innovation, economic development, structural change, and the role of history, institutions, and governance in the economy... (p.17)

If human choice and ideas can influence processes of "formation", then we are firmly in the terrain of political philosophy. Insofar as people have the power to construct and modify political and economic institutions, they need to ask if these institutions are good and just and inquire into how they should be changed. To address these and other critical issues (e.g., exploitation) inherent in the on-going economic crises, Arthur maintains that "complexity" should be used to revive "the grand tradition of political economy." (p.17)

This brings us back to the original version of institutional economics, also known as evolutionary economics, that Williamson (1985) displaced. Institutionalists were and are 
diverse, but generally share an evolutionary approach and integrated elements of law, history, and anthropology, as well as ecology to explain fundamental transitions in the nature of commerce. This broad, multi-disciplinary evolutionary approach is not easily modeled, but this in itself should alert theorists to the complexity of the systems in which they are embedded. Furthermore, the original institutional economists sought to understand how the societies arrive at their normative priorities, as well as how conflicts were resolved between traditions and technological change. In particular, these original Institutionalists provide cogent insights into the forces most dramatically exhibited in financial crises and corporate scandals of the last few decades.

For example, John R. Commons' (1862-1945) initial focus was on changing labor relations during the evolution from "merchant capitalism" to "industrial capitalism" and on toward "financial capitalism", in his four volume History of Labor in the United States (1918-1935). He also set out general parameters of the institutional approach in his classics the Legal Foundations of Capitalism (1924), and Institutional Economics (1934). Commons was among the first to notice how the evolution of finance suspended the basic cause-effect relationships of the real economy. He contended that the purpose of this sleight of hand was to wrestle the basic decisions of production out of the hands of industrialists and pass them on to the financiers. The ebb and flow of production, employment and consumption could thus be gradually taken away from travails of the market.

The greatest guide to current crises is Thorstein Veblen (1857-1929). In his classic Theory of the Leisure Class (1899), he observed how of the persistence of various "barbaric" relics (e.g., predation) could retard, or even reverse, the evolution of industry and culminate in a neofeudal "Gilded Age". Much like today, the institutions of Veblen's time amplified evolutionary distortions so as to make rent extraction much more rewarding than productive activities. In his later work, the Theory of Business Enterprise (1904), he explores this dichotomy at greater length, and explains how emerging financial motives and methods become embedded business institutions. At the peak of the industrial age, Veblen foretold the great unraveling through the consolidation of ownership and evolution into a purely "pecuniary" enterprise. That is, it was evolving from the manufacture of goods towards the manufacture of money.

Veblen was heralding the waning of the productive economy and rise of the "credit economy". The dark side of this "monetary theory of production," is that corporations would conspire with institutions to delimit competition and forestall technological advances. Furthermore, according to Veblen, fraudulent valuations, over capitalization, and underinvestment in innovation combine with unproductive consumption to fuel chronic depressions, wiping out large portions of the over-leveraged real economy in the process. Though Veblen rarely made his normative presuppositions explicit, this institutional analysis is grounded in a business ethics that situates production in a vision of a good society.

An institutional ecology approach (see: Daneke 1999) to business management has been lurking just off stage for decades. Many of its methodological antecedents can be found remnants of systems theory and cybernetics from the 1960s. Prior to Porter much of strategic management was based on the old systems theories. When the focus of systems research in the hard sciences shifted to persistent problems of nonlinearity (e.g., dissipative structures and self-organization), and computational advances made explorations of chaos and complexity mathematics more tractable, a new science of complex adaptive systems was born (see: Prigogine 1980). A small handful of social scientists joined this enterprise at the University of Michigan and Los Alamos Laboratory in New Mexico, and following the popularization of their efforts in the best seller Complexity: The Emerging Science at the Edge of Chaos and 
Order (Waldrop 1992), a few management scholars and/or corporate consultants began to take notice (e.g., Stacey 1996; Brown and Eisenhardt 1998). This interest was mostly metaphorical, epistemologically naive, and generally short-lived. However, less ambitious and more sophisticated applications of complexity methods found their way into multiple nooks and crannies of business research, especially operations management and behavioral finance (see: Farmer and Geanakoplos 2008).

Unfortunately, many of those who used the complexity tools failed to appreciate complexity concepts, and economists in particular saw it as occasionally useful addendum to neo-classical theory. As Brian Arthur (2013) explains, "complexity economics is not a special case of neoclassical economics. On the contrary, equilibrium economics is a special case of nonequilibrium and hence complexity economics (p. 19)." Moreover, it is indeed "a different framework for economic thought" (p.1), particularly if it can be integrated with traditional institutional concerns, as Arthur prescribes. An ecological approach recognizes, first and foremost, that a firm, and industry, and entire economy are living "open systems". In this regard, it shares some perspectives with "general systems theory" (see: Bertalanffy 1968). Many of the most successful applications of earlier systems thinking, however, was in closed or mechanical systems, and have little in common with the study of complex systems. The most profound distinction between the old and new systems thinking is a critical feature of complexity science generally and social systems in particular. Old systems thinking was often top down, whereas in new systems thinking complexity evolves in novel ways, from the bottom-up, through the interaction of agents. Nonetheless, this individualism is not the same as the autonomy that holds sway in the aggregate for neo-classical economics, for complexity scholars take as the unit of analysis the patterns of interaction that result in emergent properties (Epstein and Axtell 1996). Just as chaos theory is the search for order, complexity is the search for simplicity, as in simple micro rules and traits that co-evolve with emergent macro structures.

Institutional ecology using complexity tools seeks to understand under what institutional arrangements authentic industrial innovations are more likely to emerge. As Joseph Schumpeter (1912/1961) observed, technological innovations are inherently disruptive - a process he called "creative destruction". A healthy economy requires these sources of nonequilibrium. Without them the processes of adaptation and renewal quickly stagnate.

Schumpeter had faith in "spontaneous order", what we now understand to be self-organizing dynamics augmenting Darwinian gradualism at the social scale. Nonetheless, he ultimately forecast that financial capitalists would conspire to defeat his heroic entrepreneurs, and gum up the works of evolution. Beginning with the persistent extension of limited liability to financial firms as well as he explosion of unproductive wealth (Kingston 2012) amid the fortification of global mercantilism (Daneke 1998), not to mention the diversion of armies of engineers from industrial activities, the processes of financialization eventually undermined the very essence Schumpeterian innovation. As Brian Arthur (2013) points out complexity economics/political economy (which he also refers to as an "ecological approach") is especially well suited to explain how things are likely to break down, and how the interconnections broadcast or cascade the failure. Institutional ecology seeks to locate resiliency in systems, places where it is safe to fail, rather than fail safe. In late 2008, famed biologist, Robert May and his team ran a clinic, as it were, in the pages of Nature, entitled, "Complex Systems: Ecology for Bankers". Essentially it contends that banking's vast webs of counterparty risk, designed to be fail safe, are in fact a disaster of biblical proportions waiting to happen. If management scholars could be encouraged to give an ecological approach another and more earnest try, perhaps they would begin to see that the fate of firms should not be so closely wedded to the fate of the financial system. 


\section{Conclusions}

Management theorists wishing to take up the gauntlet from Ghoshal's ghost and "begin to chart a new course by laying claim to a higher purpose (Ghoshal et al. 1999: 20)" need a normative account of management theory and conceptual tools to bring it into reality. Criticism alone is insufficient. We have contended that management theorists need a new research paradigm, rooted in the social sciences, and guided by an ethical conception of a business in a just society. Theories should reflect on the function of management within a theory of justice that situates business in its larger institutional context. The old institutionalists pioneered a research program that provided conceptual tools vindicated by recent work in complexity theory and institutional ecology. These approaches, though devoid of the "pretense of knowledge" (Ghoshal 2005) of agency theory and neo-institutionalism, nonetheless provide a more realistic conception of human nature, more subtle tools for analyzing the interaction of agents under different sets of structural constraints, and a welcome modesty for practitioners attempting to intervene in complex systems. Once we recognize how bad management theories have fueled the current époque of rampant financialization, we can resurrect better management theories to serve society.

Paul Samuelson once remarked that, "in economics, it takes a theory to kill a theory; facts can only dent the hide" (cited in Boyer and Smith 2001, p.207). Enriched management approaches are required now. As suggested, economics in particular and management theory generally would be much more scientific as well as ethically enlightened if they fully integrated and not merely co-opted insights from diverse disciplines such as psychology, anthropology, and ecology - not to mention social and political philosophy and ethics. The Classical Institutionalist School (particularly Veblen) had such an orientation, and these perspectives open the door for powerful computational tools and concepts which have already demonstrated widespread applications in the physical sciences, namely Complex Adaptive Systems. Management theorists once had a faddish interest in these concepts (and a passing familiarity with the tools). It is high time for a more earnest involvement.

\section{References}

Adler, P.S. 2002. Corporate scandals: it's time for reflection in business schools. Academy of Management Executive 16(2): 148-49.

Adler, P.S. 2007. The future of critical management studies: a Paleo-Marxist critique of labour process theory. Organization Studies 28(9): 1313-45.

Alexander, J.M. 2000. Evolutionary explanations of distributive justice. Philosophy of Science 67(4): 490.

Anderson, E. 2000. Beyond Homo Economicus: new developments in theories of social norms. Philosophy and Public Affairs 29: 170-200.

Arthur, W.B. 2013. Complexity economics: a different framework for economic thought". SFI WORKING PAPE $R:$ 2013-04-012. Santa Fe: Institute for the Study of Complexity.

Association to Advance Collegiate Schools of Business. 2004. "Ethics education in business schools: Report of the Ethics Education Task Force to AACSB International's Board of Directors." http://www.aacsb.edu/ publications/researchreports/archives/ethics-education.pdf.

Baumol, W.J. 2004. On entrepreneurship, growth, and rent-seeking: Henry George updated. American Economist 48(1): 9-16.

Baumol, William J. 1990. "Entrepreneurship: Productive, unproductive, and destructive." Journal of Political Economy 98(5) Part 1: 893-921.

Boehm, C. 2012. Moral origins: The evolution of virtue, altruism, and shame. New York: Basic Books.

Bowie, N.E., and R. Edward Freeman. 1992. Ethics and agency theory: An introduction. New York: Oxford University Press. 
Bowles, S., and H. Gintis. 2011. A cooperative species: Human reciprocity and its evolution. Princeton, NJ: Princeton University Press.

Boyer, G.R., and R.S. Smith. 2001. The development of the neoclassical tradition in labor economics. Industrial and Labor Relations Review 52(2): 199-223.

Brown, S., and K.M. Eisenhardt. 1998. Competing at the edge: Strategy as structured chaos. Boston: Harvard Business School Press.

Christensen, C. 1997. The innovators' dilemma: How new technologies cause great firms to fail. Boston: Harvard Business School Press.

Christensen, L.J., E. Peirce, L.P. Hartman, W.M. Hoffman, and J. Carrier. 2007. Ethics, CSR, and sustainability education in the financial times top 50 global business schools: baseline data and future research directions. Journal of Business Ethics 73(4): 347-368.

Christopherson, S., R. Martin, and J. Pollard. 2013. Financialization: roots and repercussions. Cambridge Journal of Regions, Economy and Society 6: 351-357.

Cyert, R., and G. James. 1963. A behavioral theory of the firm. New York: Wiley.

Daneke, G.A. 1998. Beyond schumpeter: nonlinear economics and the evolution of the U.S. innovation system. Journal of Behavioral and Experimental Economics 27(1): 97-115.

Daneke, G.A. 1999. Systemic choices: Nonlinear dynamics and practical management. Ann Arbor: University of Michigan Press.

Dobbin, F., and J. Jung. 2010. The misapplication of Mr. Michael Jensen: how agency theory brought down the economy and why it might again. Research in the Sociology of Organizations 30B: $29-64$.

Donaldson, L. 2008. Ethics problems and problems with ethics: toward a pro-management theory. Journal of Business Ethics 78: 299-311.

Donaldson, T., and T.W. Dunfree. 1994. Toward a unified conception of business ethics: integrative social contracts theory. The Academy of Management Review 19(2): 252-84.

Dore, R. 2008. Financialization of the global economy. Industrial and Corporate Change 17(6): 1097-1112.

Eisenhardt, K. 1989. Agency theory: an assessment and review. Academy of Management Review 14(1): 57-74.

Epstein, G. (ed.). 2005. Financialization and the world economy. Cheltanham: Elgar Press.

Epstein, J.M., and R. Axtell. 1996. Growing artificial societies: Social science from the bottom-up. Cambridge: MIT Press.

Farmer, J.D., and J. Geanakoplos. 2008. The virtues and vices of equilibrium and the future of financial economics. Complexity 14(8): 11-38.

Fehr, E., and U. Fischbacher. 2003. The nature of human altruism. Nature 425: 785-91.

Ferraro, F., J. Pfeffer, and R.I. Sutton. 2005. Economic language and assumptions: how theories can become selffulfilling. Academy of Management Review 30(1): 8-24.

George, H. 1879. Progress and poverty, 1912th ed. Garden City: Doubleday.

Ghoshal, S. 2005. Bad management theories are destroying good management practices. Academy of Management Learning \& Education 4(1): 75-91.

Ghoshal, S., and C.A. Barlett. 1997. The individualized corporation: A fundamentally new approach to management. New York: Harper Business.

Ghoshal, S., C.A. Bartlett, and P. Moran. 1999. A new manifesto for management, 9-20. Spring: Sloan Management Review.

Giddens, A. 1984. The constitution of society: Outline of the theory of structuration. Cambridge: Polity.

Gintis, H. 2006. Behavioral ethics meets natural justice. Politics Philosophy\& Economics 5(1): 5-32.

Gintis, H.B., B.R. Samuel, and E. Fehr. 2005. Moral sentiments and material interests: On the foundations of cooperation in economic life. Cambridge: MIT Press.

Grey, C., and H. Willmott (eds.). 2005. Critical management studies: A reader. OXFORD management readers. Oxford: Oxford University Press.

Haidt, Jonathan and Wilson, David Sloan. 2013 "The grand theory of business, from Charles Darwin," Forbes, http://www.forbes.com/sites/darwinatwork/2013/10/11/.

Haldane, A.G., and R.M. May. 2011. Systemic risk in banking ecosystems. Nature 469: 351-355.

Heath, J., J. Moriarty, and N. Wayne. 2010. Business ethics and (or as) political philosophy. Business Ethics Quarterly 20(3): 427-452.

Henrich, J. 2006. Cooperation, punishment, and the evolution of human institutions. Science 312: 60-61.

Henrich, J., R. Boyd, S. Bowles, C. Camerer, E. Fehr, H. Gintis, R. McElreath, M. Alvard, A. Barr, J. Ensminger, N. Henrich, K. Hill, F. Gil-White, M. Gurven, F.W. Marlowe, J.Q. Patton, and D. Tracer. 2005. 'Economic man' in cross-cultural perspective: behavioral experiments in 15 small-scale societies. Behavioral \& Brain Sciences 28: 795-815.

Huehn, M.P. 2008. Unenlightened economism: the antecedent of bad corporate governance and ethical decline. Journal of Business Ethics 81: 823-835. 
Hühn, M.P. 2014. You reap what you sow: how mba programs undermine ethics. Journal of Business Ethics 121: $527-541$.

Jensen, M.C., and W.H. Meckling. 1976. Theory of the firm: managerial behavior, agency costs, and ownership structure. Journal of Financial Economics 3: 305-360.

Jensen, M.C., and W.H. Meckling. 1994. The nature of man. Journal of Applied Corporate Finance 7(2): 4-19.

Jones, C. 2009. Poststructuralism in critical management studies. In The Oxford Handbook of Critical Management Studies. Oxford: Oxford University Press.

Khurana, R. 2007. From higher aims to hired hands: The social transformation of American business schools and the unfulfilled promise of management as a profession. Princeton and Oxford: Princeton University Press.

Kingston, W. 2012. Schumpeter and the end of western capitalism. Journal of Evolutionary Economics 24: 449477.

Kirman, A. 2011. Complex economics. New York: Routledge.

Korten, D. 2010. Agenda for a new economy 2nd edition: From phantom wealth to real wealth. San Francisco: Berrett-Koehler Publishers.

Krippner, G. 2005. The financialization of the American economy. Socio-Economic Review 3: 173-208.

Krugman, Paul. 2009. "How did economists get it so wrong?" New York Times, September 2, http://www. nytimes.com/2009/09/06/magazine/06Economic-t.html?pagewanted=all\& r=0.

Lamont, Julian and Favor, Christi. 2014. "Distributive justice." In: The Stanford Encyclopedia of Philosophy, edited by Edward N. Zalta, http://plato.stanford.edu/archives/fall2014/entries/justice-distributive/.

Lazonick, W., and M. Mazzucato. 2013. The risk-reward nexus in the innovation-inequality relationship: who takes the risks? who gets the rewards?". Industrial and Corporate Change 22(4): 1093-1128.

Martin, R. 2002. The financialization of everyday life. Philadelphia: Temple University Press.

Martin, J. 2003. Critical theory and feminist theory. In Studying management critically, ed. A. Mats and W. Hugh. London: Sage Publications.

Mazie, Steven, V. 2011. "Rawls on wall street." New York Times, October 21, http://opinionator.blogs.nytimes. com/2011/10/21/rawls-on-wall-street/? php=true\&_type=blogs\&_r=0.

McMahon, C. 1994. Authority and democracy: A general theory of government and management. studies in moral, political, and legal philosophy. Princeton: Princeton University Press.

Melé, D. 2008. Integrating ethics into management. Journal of Business Ethics 78: 291-297.

Minsky, Hyman, P. 1992. "The financial instability hypothesis." Economics Working Paper Archive WP 74. The Levy Economics Institute.

Mirowski, P. 1991. More heat than light. New York: Cambridge University Press.

Mirowski, P. 2004. The effortless economy of science? Durham: Duke University Press.

Mirowski, P. 2013. Never let a serious crisis go to waste: How neoliberalism survived the financial meltdown. New York: Verso.

Moriarty, J. 2005. On the relevance of political philosophy to business ethics. Business Ethics Quarterly 15(3): 455-472.

Murray, Susan. 2013. "MBA teaching urged to move away from focus on shareholder primacy model." Financial Times, July 7.www.ft.com/cms/s/2/e392f12c-adac-11e2-82b8-00144feabdc0. html\#axzz3RAvjsdvR.

Norman, W. 2012. Whither business ethics? Les ateliers de l'éthique/The Ethics Forum 7(3): 31.

Olson, M. 1982. The rise and decline of nations: economic growth, stagflation, and social rigidities. New Haven: Yale University Press.

Olson, M. 2000. Power and prosperity: Outgrowing communist and capitalist dictatorships. New York: Oxford University Press.

Ostrom, E. 1990. Governing the commons: The evolution of institutions for collective action. New York, NY: Cambridge University Press.

Perez Caldentey, E., and M. Vernego. 2010. Modern finance, methodology and the global crisis. Real World Economics Review 52: 69-81.

Porter, M. 1980. Competitive strategy. New York: The Free Press.

Porter, M. 1985. Competitive advantage: Creating and sustaining superior performance. New York: Free Press. Prigogine, I. 1980. From being to becoming. San Francisco: W.H. Freeman \& Co.

Putnam, H. 2002. The collapse of the fact/value dichotomy. Cambridge: Harvard University Press.

Rawls, J. 1999. A theory of justice, revised edition. Cambridge: The Belknap Press of Harvard University Press. Rawls, J. 2001. Justice as fairness: A restatement. Cambridge: The Belknap Press of Harvard University Press. Schlefer, J. 2012. The assumptions economists make. Cambridge: The Belknap Press of Harvard University Press. Schumpeter, J A. (1912/1961). The theory of economic development, London: Oxford Univ. Press.

Sen, A. 2011. The idea of justice. Cambridge: Harvard University Press.

Simon, H. 1959. Theories of decision-making in economics and behavioral science. The American Economic Review 49(3): 253-283. 
Simon, H. 1996. The sciences of the artificial, 3rd ed. Cambridge: MIT Press.

Smith, N. Craig and Ronnegard, David. 2014. "Shareholder primacy, corporate social responsibility, and the role of business schools." Working Paper. INSEAD: The Business School of the World, http://www.insead.edu/ facultyresearch/research/doc.cfm?did=53727.

Solomon, R.C. 1990. Business ethics. In A companion to ethics, ed. S. Peter. Malden: Blackwell.

Solomon, R.C. 1993. Ethics and excellence: Cooperation and integrity in business. Oxford: Oxford University Press.

Solomon, R.C. 2004. Aristotle, ethics and business organizations. Organization Studies 25: 1021-1043.

Stacey, R. 1996. Complexity and creativity in organizations. San Francisco: Berrett-Koehler.

Stedman-Jones, D. 2012. Masters of the universe: Hayek, Friedman, and the birth of neo-liberal politics. Princeton: Princeton University Press.

Stewart, M. 2009. The management myth: Debunking modern management philosophy. New York: W.W. Norton.

Stout, L.A. 2012. The shareholder value myth. San Francisco: Berrett-Koehler Publishers, Inc.

Van der Zwan, N. 2014. Making sense of financialization. Socio-Economic Review 12(1): 99-129.

Veblen, T. 1899. The theory of the leisure class. New York: Macmillan.

Veblen, T. 1904. The theory of business enterprise. New York: Charles Scribner's Sons.

von Bertalanffy, K.L. 1968. General system theory: foundations, development, applications. New York: George Braziller.

Waldrop, M. 1992. Complexity: The emerging science at the edge of chaos and order. New York: Simon \& Schuster.

Waples, E.P., A.L. Antes, S.T. Murphy, S. Connelly, and M.D. Mumford. 2009. A meta-analytic investigation of business ethics instruction. Journal of Business Ethics 87(1): 133-151.

West D. 2011. "The purpose of the corporation in business and law school curricula." Governance Studies at Brookings, July 19.

Whalen, C.J. 2013. Post-Keynesian institutionalism after the great recession. European Journal of Economics and Economic Policies: Intervention 10(1): 12-27.

Williamson, O.E. 1964. The economics of discretionary behavior: Managerial objectives in the theory of the firm. New York: Prentice-Hall, Inc.

Williamson, O.E. 1985. The economic institutions of capitalism: Firms, markets, relational contract. New York: The Free Press.

Williamson, O.E. 1998. Transaction cost economics: how it works; where it is headed. De Economist 146(1): $23-58$.

Gregory A. Daneke received a Ph.D. from the University of California at Santa Barbara, and has held various academic posts (including the University of Michigan, Stanford University, and the University of Calgary). He is the author of over 120 scholarly publications. He was a fellow with the Governmental Accountability Office, a member of the White House Taskforce on Productivity and Innovation, and has consulted with numerous international organizations and multinational firms.

Alex Sager received his Ph.D. from the University of Calgary. He has published in Political Studies, The Critical Review of International Social and Political Philosophy, and Journal of Environmental Studies and Sciences. He edits the Broadview Guides to Business and Professional Ethics series for Broadview Press. 